\title{
Determinants of suicide attempts in a group of students - a preventive program at the university
}

\author{
Uwarunkowania prób samobójczych w grupie studentów - program profilaktyczny \\ prowadzony na uniwersytecie
}

\author{
Institute of Psychology, Maria Curie-Skłodowska University in Lublin, Lublin, Poland \\ Correspondence: Marlena Stradomska, Institute of Psychology, Maria Curie-Skłodowska University in Lublin, pl. Litewski 5, 20-080 Lublin, Poland, e-mail: stradomskamarlena@onet.pl
}

\begin{abstract}
Objective: The article summarises the reflections on the results of the research carried out in 2017-2019. The aim of the study was to analyse the causes and determinants of suicide attempts undertaken in early and middle adulthood (among students' representatives). Material and methods: The study group consisted of 425 people - students randomly selected from representatives of the Maria Curie-Skłodowska University in Lublin. Initially, the research was carried out as part of cooperation with the Support Team for People with Disabilities, and then expanded, due to the high demand for research into prevention and mental health at the university. The age of the subjects oscillated between 18 and 31 years. Representatives of individual departments came from the following provinces: Lublin, Subcarpathia, Lesser Poland and Masovia Voivodships. The test results were subjected to qualitative and quantitative analysis. Results: The analysis shows that, according to the majority of respondents, they do not know where to go for free psychological help at the university (93.6\%). On the other hand, more than half of respondents believe that suicidal behaviour in a student representative may cause, for example the Werther effect, the desire to imitate a similar act (68.5\%). Students believe that social ties during academic learning are becoming less and less strong. They believe that many people do not react to other people's problems, and even threatening situations are often ignored (52.5\%). Conclusions: there is a need for education, prevention and stimulation of social interest in the subject of self-destruction, suicide attempts or behaviours threatening the individual's health and life.
\end{abstract}

Keywords: suicide, prevention, university, students

Cel: Artykuł podsumowuje wyniki badań przeprowadzonych w latach 2017-2019. Cel badań stanowiła analiza uwarunkowań prób samobójczych podejmowanych w okresie wczesnej i średniej dorosłości. Materiał i metody: Grupa badana składała się z 425 osób - losowo wybranych studentów Uniwersytetu Marii Curie-Skłodowskiej w Lublinie. Początkowo badania realizowano w ramach współpracy z Zespołem ds. Obsługi Osób Niepełnosprawnych UMCS. Następnie zostały one rozszerzone z powodu dużego zapotrzebowania na aktualną wiedzę dotyczącą profilaktyki i ochrony zdrowia psychicznego na uniwersytecie. Wiek badanych mieścił się w przedziale 18-31 lat. Przedstawiciele poszczególnych wydziałów pochodzili z województw lubelskiego, podkarpackiego, małopolskiego i mazowieckiego. Wyniki poddano analizie ilościowej i jakościowej. Wyniki: Analiza wskazuje, że aż 93,6\% badanych nie wie, dokąd można udać się po darmową pomoc psychologiczną na uniwersytecie. Zdaniem ponad połowy uczestników badania zachowania suicydalne u studentów mogą zostać wywołane przez efekt Wertera, czyli chęć naśladowania podobnego czynu (68,5\%). Studenci uważają, że kontakty społeczne podczas nauki akademickiej stają się coraz bardziej ograniczone; wiele osób nie reaguje na problemy innych, a sytuacje zagrażające życiu często są ignorowane (52,5\%). Wnioski: Istnieje potrzeba edukacji i profilaktyki, a także rozbudzenia zainteresowania społecznego tematyką autodestrukcji, prób samobójczych oraz innych zachowań zagrażających zdrowiu i życiu jednostki.

Słowa kluczowe: samobójstwo, profilaktyka, uniwersytet, studenci 


\section{INTRODUCTION}

I $\mathrm{n}$ the $21^{\text {st }}$ century, suicides remain taboo, despite the unquestionable development of knowledge (Napieralska, 2010). Meanwhile, suicides include representatives of all social classes and professions, regardless of age, place of residence, socio-economic factors and others (Brodniak, 2012). People who attempt suicide often consider themselves weak and helpless (Płużek, 1997). In addition to deaths due to typical causes (advanced age, illness, accident), deaths resulting from suicide are becoming more common (Hołyst, 2002). This act is perceived as stigmatising, embarrassing, and threatening the family, the closest environment and even the whole community (Hołyst et al., 2002), which leads to concealing the truth or ignoring the subject of suicides (Barber et al., 1998). In certain groups, the risk of suicide is definitely higher. These include people experiencing trauma and self-injuring, the ones suffering from mental disorders, and people who have encountered family pathology (Gmitrowicz et al., 2015). Due to the lack of pathognomonic determinants, suicide risk assessment should be based on indirect indicators - primarily on the occurrence of suicidal thoughts and plans, and intention of death (Stein et al., 1998). Additional analysis covers co-occurrence of mental disorders, psychosocial situation, protective factors, individual's strengths, individual differences (Hołyst, 2002). Crises or life-threatening situations are often associated with the local environment - this also applies to the campus of the Maria Curie-Skłodowska University, where the presented research was carried out.

Suicidal behaviours that are not caused by mental illness arise from the interaction of numerous factors: individual, family, environmental ones (Shreve and Kunkel, 1991). There is a department for the disabled at every university in Poland (the name is inadequate, as the scope of its activities is much wider). Specialists employed there have psychological and social knowledge and are able to direct the student to the right place to help solve a given problem (psychologist, psychiatrist, competent institution). The article describes selected places where students from various universities - the University of Warsaw, Jagiellonian University and the University of Opole - can get help.

A statement that knowledge about suicidal hazards in a population is important sounds like a cliché. High educational requirements in the absence of adequate support, or a negative social climate are among the factors that can increase suicide risk among students. Lack of close interpersonal relationships and impersonal treatment can also affect students' daily lives. Other risk factors include the lack of interest in students' problems from the peers or the university authorities as well as the lack of the possibility of referring for psychological support (Hołyst, 2002).

\section{SPECIFICITY OF SUICIDES}

Since the causes of suicides vary, there is no single effective method of their prevention (Fundacja Zobacz...JESTEM:

\section{WSTĘP}

$\mathrm{W}$ XXI wieku, mimo niewątpliwego rozwoju wiedzy, samobójstwa pozostają tematem tabu (Napieralska, 2010). Tymczasem wśród samobójców są przedstawiciele wszystkich klas społecznych i zawodów, niezależnie od wieku, miejsca zamieszkania, czynników społeczno-ekonomicznych i innych (Brodniak, 2012). Osoby podejmujące próby samobójcze często uważają się za jednostki słabe i bezradne (Płużek, 1997). Oprócz zgonów następujących z przyczyn typowych (zaawansowany wiek, choroba, wypadek) coraz powszechniejsze stają się zgony będące rezultatem samobójstwa (Hołyst, 2002). Akt ten traktowany jest jako stygmatyzujący, wstydliwy i zagrażający rodzinie, najbliższemu środowisku, a nawet całej społeczności (Hołyst et al., 2002), co prowadzi do ukrywania prawdy czy pomijania tematu samobójstw (Barber et al., 1998).

W określonych grupach zagrożenie samobójstwem jest zdecydowanie większe - mowa tu o osobach doświadczających traumy, dokonujących samouszkodzeń, cierpiących na zaburzenia psychiczne oraz o ludziach, którzy zetknęli się z patologią rodzinną (Gmitrowicz et al., 2015). Z powodu braku wyznaczników patognomonicznych ocena ryzyka samobójstwa powinna opierać się na wskaźnikach pośrednich - przede wszystkim na występowaniu myśli i planów suicydalnych, intencji śmierci (Stein et al., 1998). Dodatkowej analizie podlegają: współwystępowanie zaburzeń psychicznych, sytuacja psychospołeczna, czynniki ochronne, mocne strony jednostki, różnice indywidualne (Hołyst, 2002). Sytuacje kryzysowe lub zagrażające zdrowiu i życiu często są związane ze środowiskiem lokalnym - dotyczy to również miasteczka akademickiego Uniwersytetu Marii Curie-Skłodowskiej (UMCS), gdzie przeprowadzono prezentowane tu badania.

Zachowania samobójcze, które nie są wywołane przez chorobę psychiczną, powstają w wyniku interakcji licznych czynników: indywidualnych, rodzinnych, środowiskowych (Shreve i Kunkel, 1991). Na każdym uniwersytecie w Polsce istnieje dział dla osób niepełnosprawnych (nazwa jest nieadekwatna, gdyż zakres działań jest o wiele szerszy). Specjaliści tam zatrudnieni dysponują wiedzą psychologiczno-społeczną i są w stanie skierować studenta $\mathrm{w}$ odpowiednie miejsce, aby pomóc $\mathrm{w}$ rozwiązaniu danego problemu (psycholog, psychiatra, właściwa instytucja). W artykule opisane zostały wybrane miejsca, w których studenci różnych uniwersytetów - Uniwersytetu Warszawskiego, Jagiellońskiego i Opolskiego - mogą uzyskać pomoc.

Za truizm należy uznać stwierdzenie, że wiedza na temat zagrożeń suicydalnych w populacji jest istotna. Wśród czynników, które mogą powodować wzrost ryzyka samobójczego wśród studentów, są wysokie wymagania edukacyjne przy braku odpowiedniego wsparcia czy negatywny klimat społeczny. Brak bliskich relacji interpersonalnych i bezosobowe traktowanie również mogą rzutować na codzienne życie osób uczących się. Kolejne czynniki ryzyka to brak zainteresowania problemami studentów ze strony rówieśników lub władz uniwersyteckich, a także brak możliwości skorzystania ze wsparcia psychologicznego (Hołyst, 2002). 
social campaigns and preventive actions, the problem remains unsolved and each year there are people of all ages among suicides. This applies both for Poland and, for example, Great Britain, where, despite greater opportunities to prevent suicide in the local environments, the problem is still significant (GOV.UK: Suicide prevention: resources and guidance).

According to the statistics by the General Police Headquarters (GPH) of Poland, 5,276 people committed suicide in Poland in 2017, and 5,182 - in 2018 (Zamachy samobójcze od 2017 roku). In turn, in the report by the Statistics Poland (SP) for 2016, the number of suicide attempts reached 5,405 (767 attempts were made by women). The number of fatal suicide attempts differs between the statistics of both institutions (Główny Urząd Statystyczny: Zamachy samobójcze w 2016 r.). Why do the statistical reports by GPH and SP, one of the most important institutions in Poland, differ so much in data? Well, the reason for the discrepancy is a different way of reporting. Currently, expert teams are implementing changes in the record of statistics. In GPH, modifications in the collection and generation of data on suicide have been implemented since 2012. Stp10 Form - "Suicide notification," which was implemented into the Temida Police Crime Statistics System, was changed to Form 10 in the National Police Information System - "Registration of a suicidal behaviours notification.” In 2017, the form was modified for "National Police Information System 10 - Suicide/ Suicide Attempt," which is to allow reporting of suicide data even more effectively. After a number of changes in the system, it is possible to modify the notification: some data can be entered at a later date (about a month), for example, if the investigation shows that suicide did not occur (http://statystyka. policja.pl/st/wybrane-statystyki/zamachy-samobojcze).

A breakthrough in suicidology was the work by Emil Durkheim, who, in the work Le suicide. Etude de sociologie, specified that "suicide is applied to every case of death which results directly or indirectly from a positive or negative act, carried out by the victim himself, knowing that it will produce this result" (Durkheim, 1976). The results of current observations are alarming as according to the World Health Organization (Światowa Organizacja Zdrowia, Polskie Towarzystwo Suicydologiczne, 2003), more than 1,500 people take their lives every day, and 15,000 attempts to commit suicide unsuccessfully. Suicides are a huge problem in a global perspective (Mishara and Kerkhof, 2013). Suicide attempts are largely the result of pathologies occurring in individuals, but this phenomenon cannot be interpreted without taking into account social issues - suicides committed due to difficult socio-economic conditions are also noted (Woźniak, 2009). Prevention, remedies and cultivating positive values can help even in a crisis. The sense of meaning in life is also important and serves as a protective factor in a suicidal situation. The sense of meaning of life is one of the basic needs the situation in which it is not met can have many negative consequences (Klamut, 2004). There are organizations and associations in Poland that, according to their statutes, support people with suicidal tendencies. An example would be

\section{SPECYFIKA SAMOBÓJSTW}

Ponieważ przyczyny samobójstw są zróżnicowane, nie istnieje jedna skuteczna metoda profilaktyki (Fundacja Zobacz... JESTEM: Samobójstwa u młodzieży w liczbach). Mimo wielu kampanii społecznych i akcji profilaktycznych problem pozostaje nierozwiązany i każdego roku wśród samobójców są osoby ze wszystkich grup wiekowych. Dzieje się tak zarówno w Polsce, jak i przykładowo w Wielkiej Brytanii, gdzie pomimo większych możliwości zapobiegania samobójstwom w środowiskach lokalnych problem wciąż jest istotny (GOV. UK: Suicide prevention: resources and guidance). Zgodnie ze statystykami Komendy Głównej Policji (KGP) w 2017 roku samobójstwo popełniło w Polsce 5276 osób, a w 2018 roku - 5182 osoby (Zamachy samobójcze od 2017 roku). Z kolei w raporcie Głównego Urzędu Statystycznego (GUS) za rok 2016 liczba prób samobójczych sięgnęła 5405 (767 prób podjęły kobiety). Liczba prób samobójczych zakończonych zgonem różni się między statystykami prowadzonymi przez obie wymienione instytucje (Główny Urząd Statystyczny: Zamachy samobójcze w 2016 r.). Dlaczego KGP i GUS, jedne z najważniejszych instytucji w Polsce, prezentują raporty statystyczne aż tak różniące się danymi? Otóż przyczyną rozbieżności jest odmienny sposób raportowania. Obecnie zespoły eksperckie wdrażają zmiany w prowadzeniu statystyk. W KGP od 2012 roku zachodzą modyfikacje w gromadzeniu i generowaniu danych dotyczących samobójstw. Druk stp10 - „Zgłoszenie zamachu samobójczego”, który był wprowadzany do systemu PSSP Temida, został zmieniony na formularz KSIP 10 - „Rejestracja zgłoszenia zamachu samobójczego”. W 2017 roku nastąpiła modyfikacja formularza na rzecz „KSIP 10 - zgłoszenie zamachu/zachowania samobójczego", co ma pozwolić jeszcze skuteczniej raportować dane dotyczące samobójstw. Po szeregu zmian w systemie istnieje możliwość modyfikacji zgłoszenia: niektóre dane można wprowadzić w późniejszym terminie (około miesiąca), przykładowo jeśli po zakończeniu dochodzenia okaże się, że jednak nie doszło do zamachu samobójczego (http://statystyka. policja.pl/st/wybrane-statystyki/zamachy-samobojcze).

Przełomem w suicydologii było dzieło Emila Durkheima, który w pracy Le suicide. Étude de sociologie dookreślił, że „samobójstwo to każdy przypadek śmierci będący bezpośrednim lub pośrednim wynikiem działania lub zaniechania przejawionego przez ofiarę zdającą sobie sprawę ze skutków swojego zachowania" (Durkheim, 1976). Wyniki aktualnych obserwacji są alarmujące, ponieważ według Światowej Organizacji Zdrowia (Światowa Organizacja Zdrowia, Polskie Towarzystwo Suicydologiczne, 2003) każdego dnia życie odbiera sobie ponad 1500 osób, a 15000 podejmuje nieudane próby samobójcze. Samobójstwa stanowią olbrzymi problem w perspektywie globalnej (Mishara i Kerkhof, 2013). Próby samobójcze w dużej mierze są efektem patologii występujących u jednostek, ale nie można interpretować tego zjawiska bez uwzględniania kwestii społecznych - notuje się bowiem również samobójstwa popełniane ze względu na trudne warunki społeczno-ekonomiczne (Woźniak, 2009). 
the Polish Suicidological Association, which brings together practitioners and specialists who provide help to people at risk of suicide (Polskie Towarzystwo Suicydologiczne: Statut Polskiego Towarzystwa Suicydologicznego). Activities to promote health - including mental health - undertaken in schools and colleges increase public awareness regarding mental problems, ways of dealing with difficulties or the ability to help others who need support.

O'Connor and Sheehy (2002) believe that communication and feedback received from the family members have a great impact on the formation of personality and self-esteem in the early and middle adulthood. Unfortunately, family, which is the basic social unit, is often disorganised. Rapid changes, professional work, responsibilities and lack of time make it difficult to develop a proper family relationship (O'Connor and Sheehy, 2002). According to Harrod et al. (2014), contact with people who are properly trained and able to recognise a presuicidal syndrome (changes in behaviour, depression, frequent statements about death, adaptation difficulties, giving away one's properties with commentary that is will not be needed any more, low self-esteem, changes in appearance) is very important for people in a suicidal crisis. People sensitised to the above-mentioned signs (after training) are able to make faster and more reliable attempts to help, which may prove useful and even save someone's life in a difficult situation. People experiencing a suicidal crisis often - but not always - communicate that they experience difficulties, and often their behaviour suggests that they experience negative emotions. Occupational groups that should have knowledge about crisis intervention are certainly college employees: lecturers, security guards, cleaning staff, people allocating accommodation, porters, and administrators of dormitory and university buildings. Godoy Garraza et al. (2018) claim that responding to suicidal risk requires immediate evaluation of threatening symptoms. It has been proven that a professional conversation with a suicidal person may be enough to dissuade them from taking their life. On the basis of a pilot study on suicide prophylaxis, Gask et al. (2017) are developing training programs with a specific university profile, which may become the basis for prevention at universities in the future.

\section{PURPOSE OF THE RESEARCH}

The article summarises only a part of the research. The project will be continued in the academic year 2019/2020 - in order to examine a larger group of respondents.

The following research goals were indicated:

- establishing motives for suicide attempts in the early and middle adulthood (a group of students);

- defining areas and scope of assistance for people after a suicide attempt;

- analysis of suicidal threats in students.

Additional goals arising from the project are:

- broadening knowledge about the causes of suicide attempts in the population of student;

- developing preventive strategies for people after a suicide attempt;
Profilaktyka, środki zaradcze i pielęgnowanie pozytywnych wartości mogą pomóc nawet w sytuacji kryzysowej. Istotne jest także poczucie sensu życia, będące czynnikiem ochronnym w sytuacji suicydalnej. Sens życia stanowi jedną z podstawowych potrzeb - jeśli nie jest ona zaspokojona, może to wywoływać wiele negatywnych konsekwencji (Klamut, 2004). W Polsce istnieją organizacje i stowarzyszenia, które zgodnie ze swoim statutem wspierają osoby $z$ tendencjami samobójczymi. Przykładem może być Polskie Towarzystwo Suicydologiczne, które zrzesza praktyków i specjalistów świadczących pomoc ludziom zagrożonym samobójstwem (Polskie Towarzystwo Suicydologiczne: Statut Polskiego Towarzystwa Suicydologicznego). Działania na rzecz promocji zdrowia, również zdrowia psychicznego, podejmowane w szkołach i uczelniach zwiększają świadomość społeczną dotyczącą problemów psychicznych, sposobów radzenia sobie z trudnościami czy umiejętności pomagania innym, którzy potrzebują wsparcia. O’Connor i Sheehy (2002) uważają, że komunikacja oraz informacje zwrotne otrzymywane od najbliższych mają duży wpływ na kształtowanie osobowości, poczucia wartości czy samooceny we wczesnej i średniej dorosłości. Niestety, rodzina - podstawowa komórka społeczna - często ulega dezorganizacji. Szybkie tempo zmian, praca, obowiązki i brak czasu powodują, że wykształcenie poprawnych stosunków rodzinnych staje się trudne (O’Connor i Sheehy, 2002). Według Harroda i wsp. (2014) bardzo ważny dla osób w kryzysie suicydalnym jest kontakt z ludźmi odpowiednio przeszkolonymi i umiejącymi rozpoznać zespół presuicydalny (zmiana zachowania, przygnębienie, częste mówienie o śmierci, trudności adaptacyjne, oddawanie swoich rzeczy z komentarzem, że już nie będą potrzebne, zaniżona samoocena, zmiany w wyglądzie). Osoby uwrażliwione na wymienione wyżej oznaki są w stanie szybciej i pewniej (po przeszkoleniu) podjąć rozmaite próby pomocy, które w sytuacji trudnej mogą okazać się przydatne, a nawet uratować komuś życie. Ludzie przeżywający kryzys suicydalny często - ale nie zawsze komunikują, że doświadczają trudności, a nierzadko również ich zachowanie sugeruje, że odczuwają negatywne emocje.

Do grup zawodowych, które powinny dysponować wiedzą na temat interwencji kryzysowej, należą z pewnością pracownicy szkół wyższych: wykładowcy, ochroniarze, personel sprzątający, osoby przydzielające zakwaterowanie, portierzy, administratorzy domów studenckich czy budynków uniwersytetu. Godoy Garraza i wsp. (2018) twierdzą, że odpowiednie reagowanie na ryzyko samobójcze wymaga natychmiastowej oceny zagrażających symptomów. Wykazano, iż profesjonalne przeprowadzenie rozmowy z osobą mającą skłonności samobójcze może wystarczyć, by odwieść ją od zamiaru odebrania sobie życia. Gask i wsp. (2017), na podstawie badania pilotażowego dotyczącego profilaktyki samobójstw, opracowują szkolenia o specyficznym profilu uniwersyteckim, które w przyszłości mogą stać się podstawą profilaktyki na uczelniach.

\section{CEL BADAŃ}

Artykuł stanowi podsumowanie jedynie części prowadzonych badań. Projekt będzie kontynuowany w roku 
- promotion of mental health among the students and employees of Maria Curie-Skłodowska University using forms of support available at the university (Friendly University project, psychological counselling, trainings organised by the Department of Competence Development and the Support Team for People with Disabilities) and new trainings that are directed to students and employees;

- building a social support network for students and employees;

- preventing suicides by increasing the support competences of both students operating in various student organisations and employees associated with psychological counselling at Maria Curie-Skłodowska University;

- cooperation with organisations dealing with suicidological issues.

\section{MATERIAL AND METHODS}

\section{Material}

By July 2019, the study covered over 600 people from the community of Maria Curie-Skłodowska University. For methodological and ethical reasons, 425 randomly selected students were qualified for the final quantitative and qualitative analyses. The reason for such a significant reduction of the group was the reluctance of some participants to engage in the further research and refusal to participate due to the fear of revealing their mental or adaptive difficulties. Several people did not agree to include their answers (questionnaires or responses obtained during the interview) in the analysis and disclose the data about the direction, faculty or university in which they studied. Other respondents felt anxiety about the lack of anonymity of the presented stories or examples. Many students were also afraid that the information that they had been receiving psychiatric treatment or psychological therapies would affect their scientific development. In addition, the results of people over the age of 35, university employees as well as those studying two faculties, and the graduates of MA studies were rejected. Therefore, some of the results were not included in the analyses, in accordance with the psychologist's code of ethics.

Initially, the research was carried out in the cooperation with Maria Curie-Skłodowska University Support Team for People with Disabilities. Next, they were expanded due to the high demand for current knowledge about prevention and mental health protection at the university. Students admit that they use consultations and other forms of psychological help because these are free. Psychotherapy is unavailable for many young people due to their lack of a stable source of income (students make a living from academic or social scholarships, take up part-time jobs or receive financial support from parents).

The examined people were Maria Curie-Skłodowska University students aged 18-31. Representatives of individual departments came from the Lublin, Subcarpathia, Lesser Poland and Masovia Voivodships. The participants were first and second year students (first year - 211 people, second year - 214 people). The selection of people who had akademickim 2019/2020 - w celu przebadania większej grupy respondentów.

Sformułowano następujące cele badawcze:

- ustalenie motywów podejmowania prób samobójczych w okresie wczesnej i średniej dorosłości (grupa studentów);

- określenie obszarów i zakresu pomocy dla osób po próbie samobójczej;

- analiza zagrożeń suicydalnych u studentów.

Dodatkowe cele wynikające z projektu to:

- poszerzenie wiedzy o przyczynach prób samobójczych w populacji studentów;

- wypracowanie strategii profilaktycznych w odniesieniu do osób po próbie samobójczej;

- promowanie zdrowia psychicznego wśród studentów i pracowników UMCS z wykorzystaniem dostępnych na uczelni form wsparcia (projekt Przyjazny Uniwersytet, poradnictwo psychologiczne, szkolenia organizowane przez Biuro Rozwoju Kompetencji i Zespół ds. Obsługi Osób Niepełnosprawnych) oraz nowych szkoleń, które są skierowane do studentów i pracowników;

- budowa sieci wsparcia społecznego dla studentów i pracowników;

- zapobieganie samobójstwom przez zwiększenie kompetencji pomocowych zarówno studentów działających w różnych organizacjach studenckich, jak i pracowników związanych z poradnictwem psychologicznym na UMCS;

- współpraca z organizacjami zajmującymi się problematyką suicydologiczną.

\section{MATERIA I METODY}

\section{Materiał}

Do lipca 2019 roku badaniami objęto ponad 600 osób ze społeczności UMCS. Do ostatecznych analiz ilościowych i jakościowych, ze względów metodologicznych i etycznych, zakwalifikowano 425 losowo wybranych studentów. Powodem tak znaczącej redukcji grupy była niechęć części uczestników do angażowania się w dalsze badania i odmowa udziału ze względu na obawę przed ujawnieniem trudności psychicznych czy adaptacyjnych. Kilka osób nie zgodziło się na włączenie ich odpowiedzi (kwestionariuszowych lub uzyskanych podczas wywiadu) do analizy oraz ujawnienie danych dotyczących kierunku, wydziału albo uniwersytetu, na którym studiują. Inni badani odczuwali niepokój związany z brakiem anonimowości prezentowanych historii czy przykładów. Wielu studentów obawiało się też, że informacja, iż leczą się psychiatrycznie lub odbywają terapie psychologiczne, będzie rzutowała na ich rozwój naukowy. Dodatkowo odrzucono wyniki osób powyżej 35. roku życia, pracowników uniwersytetu, a także studiujących dwa kierunki i absolwentów studiów magisterskich. W związku z powyższym część wyników nie została włączona do analiz, zgodnie z kodeksem etycznym psychologa.

Początkowo badania prowadzono w ramach współpracy z Zespołem ds. Obsługi Osób Niepełnosprawnych UMCS. Następnie zostały one rozszerzone z powodu wysokiego 
recently started university education was due to the fact that they might have had the greatest difficulties in adapting to new environmental conditions. The test results were subjected to quantitative and qualitative analyses.

\section{Research methods}

Research carried out under the project was broad; for the purposes of the article only two tools were used and discussed below.

\section{Author's questionnaire}

The tool included 30 questions regarding:

- the current state of knowledge of the respondents (before undergoing specialist workshops);

- knowledge about behaviours and tendencies related to suicide;

- declarative knowledge about suicide (what may make students attempt suicide);

- the possibility of receiving specialist help (psychological, psychiatric);

- knowledge of preventive programs implemented at Maria Curie-Skłodowska University.

\section{Structured interview}

It was found that supplementing the study with a structured interview will increase the amount of research material related to the preventive project. In many cases, the interview has become an introduction to basic psychological consultations and a way to provide information about the possibilities of obtaining further professional help.

During the interview, the respondents were asked about the motives for suicide attempts and their own experience. The interview turned out to be an important element of the project, because over 100 people declared that before starting their studies or already at the university, they wanted to commit suicide or had suicidal thoughts. In addition, 19 participants admitted that they had been hospitalised because of psychological difficulties. Questions also concerned sources of knowledge about suicide (Internet, peer environment, social campaigns and others).

\section{RESULTS}

The selected results obtained from the questionnaire and the structured interview grouped into broader categories are discussed below. Questions for the questionnaire were prepared on the basis of existing literature, scientific achievements of researchers from Poland and abroad, and reports from various organisations, including World Health Organization. Individual questions were consulted with representatives of support institutions, practitioners treating people after suicide attempts, psychiatrists, representatives of societies which deal with mental health issues and work with people in crisis (Polish Suicidological Association, Maria Curie-Skłodowska University Support Team for People with Disabilities). In order to select the most important elements, each item of the zapotrzebowania na aktualną wiedzę dotyczącą profilaktyki i ochrony zdrowia psychicznego na uniwersytecie. Studenci przyznają, że korzystają z konsultacji i innych form pomocy psychologicznej, gdyż są one darmowe. Psychoterapia jest dla wielu młodych ludzi nieosiągalna ze względu na brak stałego źródła utrzymania (studenci utrzymują się ze stypendiów naukowych lub socjalnych, podejmują prace dorywcze albo otrzymują pomoc finansową od rodziców).

Osobami badanymi byli studenci UMCS w wieku 18-31 lat. Przedstawiciele poszczególnych wydziałów pochodzili z województw lubelskiego, podkarpackiego, małopolskiego i mazowieckiego. Uczestnicy to studenci pierwszego i drugiego roku studiów (I rok - 211 osób, II rok - 214 osób). Wybór osób, które niedawno rozpoczęły edukację uniwersytecką, wynika $\mathrm{z}$ faktu, że mogą one mieć największe trudności związane $\mathrm{z}$ adaptacją do nowych warunków środowiskowych. Wyniki badań poddano analizie ilościowej i jakościowej.

\section{Metody badawcze}

Badania realizowane $\mathrm{w}$ ramach projektu są rozbudowane, natomiast na potrzeby artykułu wykorzystano jedynie dwa narzędzia, omówione poniżej.

\section{Autorska ankieta}

Narzędzie składało się z 20 pytań, które dotyczyły:

- obecnego stanu wiedzy osób badanych (przed odbyciem warsztatów specjalistycznych);

- wiedzy na temat zachowań i tendencji związanych z samobójstwem;

- deklaratywnej wiedzy dotyczącej samobójstwa (co może sprawiać, że studenci podejmują próby samobójcze);

- możliwości otrzymania pomocy specjalistycznej (psychologicznej, psychiatrycznej);

- znajomości programów profilaktycznych realizowanych na UMCS.

\section{Wywiad ustrukturyzowany}

Stwierdzono, że rozszerzenie badania o wywiad ustrukturyzowany zwiększy ilość materiału badawczego związanego z projektem profilaktycznym. W wielu przypadkach wywiad stał się wstępem do podstawowych konsultacji psychologicznych i sposobem na przekazanie informacji o możliwościach uzyskania dalszej profesjonalnej pomocy.

Podczas wywiadu pytano o motywy podejmowania prób samobójczych oraz doświadczenia własne osób badanych. Wywiad okazał się ważnym elementem projektu, gdyż ponad 100 osób zadeklarowało, że przed rozpoczęciem studiów lub już w trakcie edukacji na uniwersytecie chciały popełnić samobójstwo bądź miały myśli samobójcze. Ponadto 19 uczestników przyznało, że byli hospitalizowani ze względu na trudności natury psychicznej. Pytania dotyczyły także źródeł wiedzy na temat samobójstwa (internet, środowisko rówieśnicze, kampanie społeczne, inne).

\section{WYNIKI}

Poniżej omówiono wybrane wyniki uzyskane za pomocą ankiety i wywiadu ustrukturyzowanego, pogrupowane 
competent judges dealing with issues related to prevention and mental health in scientific work.

\section{Author's questionnaire and the structured interview}

The question "What do you think - what difficulties, problems, difficult situations do students face most often?" could be answered with any number of options from the proposed answers (Tab. 1).

The most of participants indicated the example associated with difficulties in adaptation during studies (391 respondents, $89.7 \%$ ) - in the remarks, the respondents indicated that this also applied to homesickness or earlier life in the family home. In a structured interview, one of the students admitted that she had trouble accepting the new situation: "I am angry that there is no serious university in the city where I live. I had to leave a beautiful house that was rewritten for me, my fiancé who has a job there, lots of friends. I am alone here now. And I'm considering going to a specialist. I feel like it's a different dimension."

Difficulties in relationships were recognised by 342 respondents $(80.5 \%)$ as a possible problem in the group of students. During one of the interviews, the following words were said: "Let's look at the difference in getting along with academic teachers. In high school it was completely different. At the beginning it's a nightmare. For example, during the first year of study, I was to make several presentations in the first month - with a group of colleagues whom I had known for several days. It was very stressful for me." w szersze kategorie. Pytania ankietowe opracowywano na podstawie dotychczasowej literatury, dorobku naukowego badaczy z Polski i zagranicy oraz raportów różnych organizacji, m.in. Światowej Organizacji Zdrowia. Poszczególne pytania zostały skonsultowane z przedstawicielami instytucji pomocowych, praktykami prowadzącymi terapię osób po próbach samobójczych, psychiatrami, reprezentantami towarzystw zajmujących się tematyką zdrowia psychicznego i pracą z osobami w kryzysie (Polskie Towarzystwo Suicydologiczne, Zespół ds. Obsługi Osób Niepełnosprawnych UMCS). W celu wyboru najistotniejszych elementów każda pozycja ankiety i wywiadu była konsultowana i analizowana przez sędziów kompetentnych zajmujących się w pracy naukowej zagadnieniami związanymi z profilaktyką i zdrowiem psychicznym.

\section{Autorska ankieta i wywiad ustrukturyzowany}

Na pytanie „Jak Pan/Pani uważa - z jakimi trudnościami, problemami, sytuacjami trudnymi najczęściej zmagają się studenci?" osoby badane mogły odpowiedzieć, wybierając dowolną liczbę odpowiedzi spośród zaproponowanych (tab. 1). Najwięcej uczestników zaznaczyło przykład związany z trudnościami z adaptacją na studiach (391 badanych, 89,7\%) w uwagach ankietowani zaznaczali, że dotyczy to także tęsknoty za domem czy wcześniejszym życiem w domu rodzinnym. Jedna ze studentek w wywiadzie ustrukturyzowanym przyznała, że miała problem $\mathrm{z}$ akceptacją nowej sytuacji: „Jestem zła, że w mieście, w którym mieszkam, nie ma żadnego poważnego uniwersytetu. Musiałam zostawić piękny

\begin{tabular}{|c|c|c|c|}
\hline $\begin{array}{l}\text { No. } \\
\text { Lp. }\end{array}$ & $\begin{array}{l}\text { Example } \\
\text { Przykład }\end{array}$ & $\begin{array}{l}\text { Indications } \\
\text { Wskazania }\end{array}$ & $\begin{array}{l}\text { Percent } \\
\text { Wykaz procentowy }\end{array}$ \\
\hline 1. & $\begin{array}{l}\text { Difficulties with adaptation in college (longing for home/previous experiences, problems adapting to the new reality) } \\
\text { Trudności z adaptacja na studiach (tęsknota za domem/wcześniejszymi doświadczeniami, problemy z przystosowaniem się do nowej } \\
\text { rzeczywistości) }\end{array}$ & 381 & $89.7 \%$ \\
\hline 2. & \begin{tabular}{|l} 
Difficulties in relations (in communication) \\
Trudności w relacjach (w komunikacji)
\end{tabular} & 342 & $80.5 \%$ \\
\hline 3. & $\begin{array}{l}\text { Mental difficulties (mental illness and disorders, nervous breakdown) } \\
\text { Trudności natury psychicznej (choroby i zaburzenia psychiczne, załamanie nerwowe) }\end{array}$ & 318 & $74.8 \%$ \\
\hline 4. & $\begin{array}{l}\text { Financial difficulties (sponsorship, difficulties making a living, the necessity to take up a job and reconcile it with education) } \\
\text { Trudności finansowe (sponsoring, trudności z utrzymaniem się, konieczność podjęcia pracy zawodowej i pogodzenia jej z nauka) }\end{array}$ & 317 & $74.5 \%$ \\
\hline 5. & $\begin{array}{l}\text { Difficulties in love life } \\
\text { Trudności milosne }\end{array}$ & 274 & $64.5 \%$ \\
\hline 6. & $\begin{array}{l}\text { Low self-esteem (no sense of agency) } \\
\text { Niska samoocena (brak poczucia sprawczości) }\end{array}$ & 261 & $61.4 \%$ \\
\hline 7. & $\begin{array}{l}\text { Health problems } \\
\text { Problemy ze zdrowiem }\end{array}$ & 223 & $52.5 \%$ \\
\hline 8. & $\begin{array}{l}\text { Difficulties in learning (problems with passing the exams) } \\
\text { Trudności w nauce (kłopoty z zaliczeniem sesji) }\end{array}$ & 212 & $49.9 \%$ \\
\hline 9. & $\begin{array}{l}\text { Addictions (drugs, boosters, alcohol) } \\
\text { Uzależnienia (narkotyki, dopalacze, alkohol) }\end{array}$ & 199 & $46.9 \%$ \\
\hline 10. & $\begin{array}{l}\text { Engaging in risky situations (accidental sex, unprotected sex, sexual experiments, taking drugs or boosters, inviting strangers } \\
\text { home, driving a motor vehicle after drinking alcohol, climbing high buildings, etc.) } \\
\text { Angażowanie się w sytuacje ryzykowne (przygodny seks, seks bez zabezpieczenia, eksperymenty seksualne, zażywanie narkotyków czy dopalaczy, } \\
\text { zaproszenie do domu osoby nieznajomej, jazda pojazdem mechanicznym po spożyciu alkoholu, wspinanie się na wysokie budynki itd.) }\end{array}$ & 88 & $20.7 \%$ \\
\hline
\end{tabular}

Tab. 1. What do you think - what difficulties, problems, difficult situations do students face most often?

Tab. 1. Jak Pan/Pani uważa - z jakimi trudnościami, problemami, sytuacjami trudnymi najczéściej zmagają się studenci? 
Mental difficulties were indicated by 318 people (74.8\%). Here is an example of a respondent's statement: "A doctor in my city told me that changing the environment would be good for me. Well, maybe, but during the first year of study it was a tragedy, I did not forget about the trauma, I even isolated myself from the new environment so that something bad would not happen again. If you have depression, it doesn't matter where you are."

According to 317 people (74.5\%), financial problems can be a difficulty for students. One of the women shared the following observation: "I was lucky because I was getting money from my parents, but there were friends who were looking for quick earnings and sometimes dated married men for an obvious purpose."

274 respondents indicated problems in love life (64.5\%). Difficult experiences with close relationships can increase the risk of suicide: "My colleague from the hostel had a nice boyfriend, but she learned that he had been cheating on her. At the last second, I called her parents because I accidentally found 100 tablets of paracetamol and other stuff in her bag." It is worth to emphasise that individual differences as well as attitude towards relationships, play a significant role here: "University studies is the time when one tries many different things, one can also have an unlimited number of relationships. Sometimes too many, if you know what I mean. It is also the cause of various difficulties, for example as one starts to understand that he or she is in fact alone. And these disco or club relationships mean nothing."

Low self-esteem, lack of sense of agency, self-confidence and lack of faith in their abilities were indicated by 261 respondents (61.4\%). A good example is the fragment of a survey completed by a 21-year-old woman: "I was always in a worse situation because I was studying $24 / 7$ and thought I still knew nothing. My perfectionism led to sleeplessness. The worst moment - and then I woke up - was that I fell asleep (lost touch with reality) during the most important exam in college. I was so exhausted and destroyed by coffee and energy. It was only after this situation that I sought help."

According to $52.5 \%$ of respondents (223 people), health problems may be a difficulty for young adults. Here is one of the statements: "I suffer from a serious illness, but my group from college has behaved great. They organised a collection for me, they worried and cared for me, but I know that there was no such support in other departments. Not everyone is lucky." For 212 people (49.9\%), serious difficulties are associated with studying and taking exams. A law student wrote: "Over the first three years of study, over 100 people dropped out. And they were not people who had not been predisposed and had not study. I know some of them finished badly. Some even pretended to the family for several months after being thrown out that they were great students until the letter came home." According to $46.9 \%$ of respondents (119 people), addictions may become a difficulty. Here is an example: "It's usually believed that it's not addiction, but beer with friends. Some students break off the chain and quickly one bottle of beer dom, który jest przepisany na mnie, narzeczonego, który ma tam pracę, masę znajomych. Teraz tutaj jestem sama. I rozważam pójście do specjalisty. Czuję, jakby to był inny wymiar”. Trudności w relacjach zostały uznane przez 342 ankietowanych $(80,5 \%)$ za możliwy problem w grupie studentów. Podczas jednego z wywiadów padły następujące słowa: „Spójrzmy na to, jaka jest różnica w dogadywaniu się z nauczycielami akademickimi. W liceum było zupełnie inaczej. $\mathrm{Na}$ początku to koszmar. Ja np. na pierwszym roku studiów już w pierwszym miesiącu miałam zrobić kilka prezentacji i to z grupą kolegów, których znałam kilka dni. To było dla mnie bardzo stresujące".

Trudności natury psychicznej zostały wskazane przez 318 osób (74,8\%). Oto przykładowa wypowiedź respondenta: „Mnie lekarz w moim mieście powiedział, że zmiana otoczenia w mojej sytuacji będzie dobra. Może i tak, ale przez pierwszy rok studiów była to tragedia, nie zapominałem o traumach, a wręcz izolowałem się od nowego otoczenia, żeby znów się nie stało coś złego. Jak się ma depresję, to niezależnie od miejsca”.

Zdaniem 317 osób (74,5\%) trudnością dla studentów mogą być kłopoty finansowe. Jedna $\mathrm{z}$ kobiet podzieliła się następującą obserwacją: „Ja miałam szczęście, bo dostawałam pieniądze od rodziców, ale były koleżanki, które szukały szybkiego zarobku i czasem spotykały się z żonatymi facetami w wiadomym celu".

Problemy miłosne wskazało 274 respondentów (64,5\%). Trudne doświadczenia związane $z$ bliskimi relacjami mogą wzmagać ryzyko samobójstwa: „Moja koleżanka $\mathrm{z}$ akademika miała fajnego chłopaka, ale dowiedziała się o zdradzie. W ostatniej chwili zadzwoniłam po jej rodziców, bo przez przypadek w jej torebce znalazłam ze 100 tabletek paracetamolu i innego syfu". Warto zaznaczyć, że dużą rolę odgrywają tu różnice indywidualne, a także stosunek do związków: „Studia to czas, w którym próbuje się wielu różnych rzeczy, można mieć też nieograniczoną ilość miłości. Czasem aż za dużo, jeśli wiadomo, o co mi chodzi. To też przyczyna różnych trudności, jak się np. zrozumie, że człowiek i tak jest sam. A te relacje z dyskoteki lub klubu nic nie znaczą".

Niska samoocena, brak poczucia sprawczości oraz wiary w siebie i swoje możliwości zostały wskazane przez 261 ankietowanych $(61,4 \%)$. Jako przykład może tutaj posłużyć fragment ankiety wypełnionej przez 21-letnią kobietę: „Ja miałam zawsze gorzej, bo uczyłam się 24/7 i dalej myślałam, że nie umiem. Mój perfekcjonizm nie dawał mi spać. Najgorszym momentem - wtedy się ocknęłam - było to, że zasnęłam (straciłam kontakt $\mathrm{z}$ rzeczywistością) na najważniejszym na studiach egzaminie. Byłam tak wykończona i wyniszczona przez kawę, energetyki. Dopiero po tej sytuacji poszukałam pomocy".

Według 52,5\% respondentów (223 osoby) dla młodych dorosłych trudnością mogą być problemy ze zdrowiem. Oto jedna z wypowiedzi: „Jestem chora na poważną chorobę, ale moja grupa ze studiów zachowała się super. Zrobili dla mnie zbiórki, martwili się, troszczyli, ale wiem, że na innych wydziałach nie było takiego wsparcia. Nie każdy jest szczęściarzem”. 
it is not difficult to have a good atmosphere, but most often you cannot do without a before-party and an after-party." When it comes to engaging in risky situations - accidental sex, unprotected sex, taking illegal substances and others -88 respondents (20.7\%) said that such behaviours do occur and can lead to negative consequences in health and life. One of the students shared a story from the recent past: "My friends and I had such a challenge that after each party we picked up a guy. At first it was fun, yet later this fun with feelings ended fatally for a few of us, because several of these men turned out to be stalkers."

When asked about psychological help in case of difficulties, a large proportion of respondents (43\%) replied that they did not know if they would accept help, 19\% of respondents would not like any support, and 38\% - would use the available support options (Fig. 1). Many respondents believe that the environment could perceive it improperly. It applies particularly to the respondents who intend to work in professions of social trust. It is worth quoting the student's statement here: "For me it is unprofessional to study law and have difficulties of this nature; I cannot imagine how I would work in court and get sick myself. Legal training is now the most important."

Most respondents (22\%) said that mental illnesses contribute to students' suicides. Structured interviews show that "at the university, it is not known who suffers from which disease. Even in social, psychological or pedagogical studies, there are no preliminary talks or screening tests."

Slightly fewer (19\% of respondents) said that the lack of financial support may lead to thinking about suicide: "Well, I can talk about myself, I felt tired of studying when I was forced to work in a supermarket, and I didn't have enough time to study and write essays. I doubted my life then."

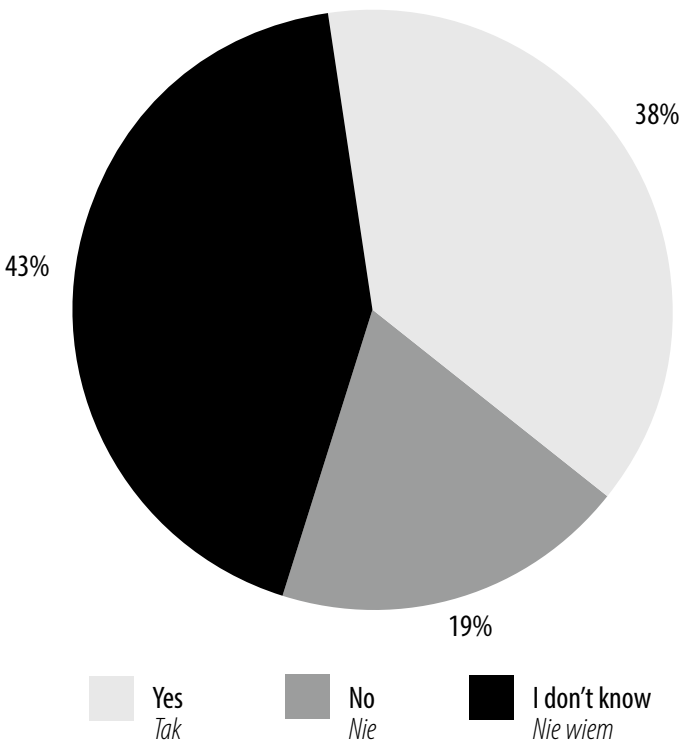

Fig. 1. Willingness to receive professional help related to mental health

Ryc. 1. Chęć uzyskania profesjonalnej pomocy zwiazanej ze zdrowiem psychicznym
Dla 212 osób (49,9\%) poważne trudności wiążą się z nauką, zdawaniem egzaminów. Jak napisał student prawa: „U nas przez pierwsze trzy lata studiowania odpadło ponad 100 osób. I to nie były osoby, które nie miały predyspozycji i się nie uczyły. Wiem, że część z nich źle skończyła. Niektórzy nawet przez kilka miesięcy po wyrzuceniu udawali przed rodziną, że są świetnymi studentami, dopóki do domu nie przyszedł list".

Zdaniem 46,9\% ankietowanych (119 osób) trudnością mogą się stać uzależnienia. Oto przykładowa wypowiedź: „Zazwyczaj się mówi, że to nie uzależnienie, a piwo z kolegami. Niektórzy studenci urywają się z łańcucha i z jednego piwa robi się jedna flaszka, na rozluźnienie. W miastach studenckich nie jest trudno o dobrą atmosferę, ale najczęściej nie obchodzi się bez beforu i afteru"'.

Jeżeli chodzi o angażowanie się w sytuacje ryzykowne - przygodny seks, seks bez zabezpieczenia, zażywanie nielegalnych substancji i inne - to 88 respondentów (20,7\%) uznało, że podobne zachowania się zdarzają i mogą prowadzić do negatywnych konsekwencji dla zdrowia i życia. Jedna ze studentek podzieliła się historią z nieodległej przeszłości: „Miałyśmy z koleżankami takie wyzwanie, że po każdej imprezie wyrywamy faceta. Na początku to było zabawne, a później dla kilku z nas ta zabawa z uczuciami skończyła się fatalnie, bo kilku z tych panów okazało się stalkerami”.

$\mathrm{Na}$ pytanie dotyczące pomocy psychologicznej w razie napotkania trudności duża część osób (43\%) odpowiedziała, że nie wie, czy chciałaby pomocy; 19\% badanych nie życzyłoby sobie żadnego wsparcia, a 38\% skorzystałoby z dostępnych opcji pomocowych (ryc. 1). Wielu respondentów uważa, że otoczenie mogłoby to potraktować niewłaściwie. W szczególności sądzą tak ankietowani, którzy zamierzają wykonywać zawody zaufania społecznego. Warto tu zacytować wypowiedź studentki: „Dla mnie to nieprofesjonalne studiować prawo i mieć trudności tej natury, nie wyobrażam sobie, jak miałabym pracować w sądzie i sama chorować. Najważniejsza jest teraz aplikacja”.

Najwięcej respondentów (22\%) uznało, że do samobójstw wśród studentów przyczyniają się choroby psychiczne. $\mathrm{Z}$ wywiadu ustrukturyzowanego wynika, iż „na studiach przecież nie wiadomo, kto ma jaką chorobę. Nawet na studiach społecznych, psychologicznych czy pedagogicznych nie ma rozmów wstępnych czy testów przesiewowych".

Nieco mniej, bo $19 \%$ badanych, stwierdziło, że do myślenia o samobójstwie może prowadzić brak wsparcia finansowego: „No, ja mogę mówić o sobie, mi się odechciało studiowania, jak musiałam pracować na siłę w markecie, a nie starczało mi czasu na naukę i pisanie prac zaliczeniowych. Wtedy mocno zwątpiłam w życie”.

Po 17\% badanych uważa, iż przyczynami prób samobójczych są trudności w adaptacji oraz brak wsparcia psychologicznego:

\footnotetext{
${ }^{1}$ Before - spożywanie alkoholu przed wyjściem na imprezę w celu wcześniejszego upojenia alkoholowego, co według ankietowanych ma być fundamentem lepszej zabawy.

After - spożywanie alkoholu po imprezie czy spotkaniu w celu jeszcze większego upojenia alkoholowego.
} 
$17 \%$ of respondents believe that the reasons for suicide attempts are difficulties in adaptation and the lack of psychological support: "A recent situation in the dorms: a foreign girl, I believe she was 17, committed suicide. She did not manage; she returned home from the university to this melting pot, she lacked hope. Later I found out from a lady in the porter's lodge that she was tearful and sad. Nobody reacted as everybody believes that students are adults."

According to $14 \%$ of respondents, suicidal threats include the lack of sense of meaning in life: "Recently, the meaning of life is trendy, a lot of publications, you can lose it at any age, but sometimes you can see how this sense is taken by depression, the death of a loved one, separation."

Finally, according to $11 \%$ of the surveyed, addiction is a threat: "It's something I experienced at the first year of study, which I did not complete. I went to a party, took a pill, boosted it with alcohol, then danced again. Suddenly I heard that I had to kill myself, I smashed the bottle and cut myself so that I had over 70 stitches" (woman, 27) (Fig. 2).

The analysis of the obtained results shows that as many as $93.6 \%$ of respondents do not know where to look for free psychological help at the university. The structured interview proved that some people thought it was a shame that young people could not cope with their lives. In addition, they do not want to lose good reputation among newly met people. Here is one of the statements: "I was a lame duck in high school, I don't want to be one now. Even if I have a problem, I go and cry at home. There were girls at the exams who started to cry, got some spasms and from that moment no one likes them." More than half of the respondents believe that suicidal

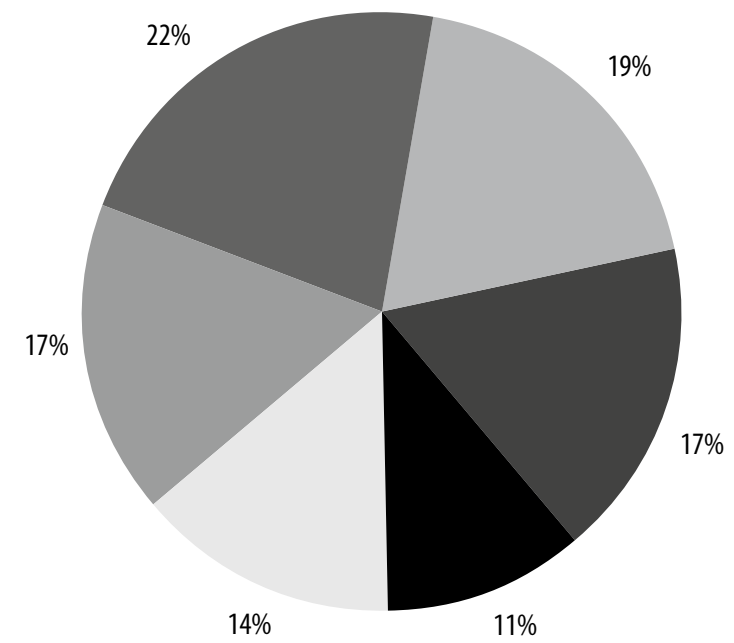

Lack of financial support Brak wsparcia finansowego

Lack of psychological support Brak wsparcia psychologicznego

Addictions

Uzależnienia

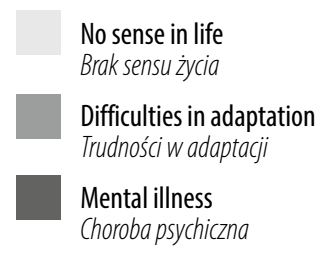

Fig. 2. Causes of suicide in an academic environment
„Ostatnio sytuacja w akademikach, dziewczyna z innego kraju, chyba miała z 17 lat, popełniła samobójstwo. Nie dała rady, jakoś wróciła z domu na uczelnię i do tego tygla, gdzieś zabrakło jej nadziei. Później dowiedziałam się od pani z portierni, że ona była płaczliwa, smutna. Nikt nie zareagował, bo uważają, że studenci są już dorośli”.

Według 14\% respondentów do zagrożeń suicydalnych należy brak poczucia sensu życia: „Ostatnio na topie jest sens życia, dużo publikacji, w każdym wieku można go stracić, ale czasem widać, jak ten sens zabiera depresja, śmierć kogoś najbliższego, rozstanie".

Wreszcie zdaniem 11\% ankietowanych zagrożeniem są uzależnienia: „Miałam tak na pierwszym kierunku studiów, którego nie dokończyłam. Poszłam na imprezę, wzięłam jakąś tabletkę, poprawiłam alkoholem, później znowu czymś, potańczyłam. Nagle usłyszałam, że muszę się zabić, rozbiłam butelkę i pocięłam się tak, że miałam ponad 70 szwów" (kobieta, lat 27) (ryc. 2).

Analiza uzyskanych wyników wskazuje, że aż 93,6\% badanych nie wie, dokąd można udać się po darmową pomoc psychologiczną na uniwersytecie. Część osób w wywiadzie ustrukturyzowanym uznała, że to wstyd, aby młode osoby nie radziły sobie ze swoim życiem. Ponadto nie chcą stracić dobrej opinii wśród nowo poznanych ludzi. Oto jedna z wypowiedzi: „Już w liceum byłam ofiarą losu, teraz tego nie chcę. Nawet jak mam problem, to idę i płaczę w domu. Były na egzaminach takie dziewczyny, które zaczynały płakać, dostawały jakichś spazmów i od tego momentu nikt ich już nie lubi na roku”. Ponad połowa badanych uważa, że zachowania suicydalne u studentów może wywoływać efekt Wertera (68,5\%). Jako przykład niech posłuży wypowiedź 22-letniej studentki: „Jak się dowiedziałam, że dziewczyna skoczyła z wysokości, a była z mojego wydziału, to stwierdziłam, że może to dobra opcja przed tymi trudnymi egzaminami, ale później się opamiętałam".

Zdaniem respondentów więzi społeczne podczas nauki akademickiej stają się coraz słabsze; wiele osób nie reaguje na problemy innych, a wręcz ignoruje sytuacje zagrażające (52,5\%). Obrazują to wypowiedzi: „Proponuję często osobom, żeby wyszły na piwo, żeby się pouczyły wspólnie, ale oni zawsze się gdzieś spieszą” oraz „Nawet jak mamy zadane prezentacje grupowe, co ma w zasadzie nas motywować do komunikacji [...], to byleby zrobić tę prezentację i do domu. Jak już wystawią ocenę, to nawet już nie ma wspólnego tematu”.

\section{OMÓWIENIE}

Wyniki przeprowadzonych badań są niepokojące ze względu na charakterystykę psychologiczną osób biorących udział w projekcie. Badania były zainspirowane doniesieniami innych naukowców, ponieważ samobójstwa są problemem globalnym. Badania realizowane w Wielkiej Brytanii, przede wszystkim na Uniwersytecie w Bristolu (University of Bristol, 2018), wskazują, że presja finansowa, trudności na studiach, słaba frekwencja na zajęciach, nadużywanie alkoholu i substancji psychoaktywnych mogą zwiększyć 
behaviours in students may be triggered by the Werther effect. An example by the 22-year-old student: "When I found out that the girl had jumped from a height and was from my faculty, I thought it might be a good option before these difficult exams, but I came to my senses later."

According to the respondents, social ties are becoming weaker during academic education; many people do not respond to the problems of others, and even ignore threatening situations (52.5\%). This is illustrated by the statements: "I often suggest people go out for a beer, learn together, but they are always in a hurry," and "Even if we have group presentations, which is supposed to motivate us to communicate [...], many of us just want to be done with the presentation and go home. After the presentation is assessed, we don't even have a common topic to discuss."

\section{DISCUSSION}

The results of the conducted research are worrying due to the psychological characteristics of the people participating in the project. The research was inspired by the reports from other scientists because suicide is a global problem. According to the research conducted in the United Kingdom, primarily at the University of Bristol (University of Bristol, 2018), financial pressure, study difficulties, poor college attendance, and the abuse of alcohol and psychoactive substances can increase the risk of suicide. Another important difficulty analysed by the scientists from the United Kingdom was that students experience a sense of failure, stress or specific learning problems (problems with remembering and understanding, too much material to process). The issues also included disability, medical, psychological and family problems of people undertaking education. Some factors, such as difficulties in accessing support, are related to the realities of university life [National Confidential Inquiry into Suicide and Homicide by People with Mental Illness (NCISH), 2017].

Despite the changes, many difficulties associated with adaptation in the new environment can be observed, also in the group of students (Zimbardo and Weber, 1997). Studying is often associated with a radical change in lifestyle, because young people move to another city, change their living conditions and must interact with other new people on a daily basis. One respondent (19 years old) shared the following story: "Suddenly I had to live in a dormitory. Without the comforts that I had at home with my parents. The roommate wasn't interested in me. I had too much freedom, I could come back home at the time I wanted, drink as much as I wanted, and do what I wanted. Later I got lost. I tried stimulants. I almost drop out of my dream faculty. It broke me and I decided to kill myself." The literature on the subject provides information on the important correlation between self-esteem and self-destructive behaviour (Hoff, 1991).

What is beneficial from the perspective of suicidal behaviour prevention, is the fact that academic employees, $\mathrm{PhD}$ students and students are increasingly willing to take action to reduce the number of suicides. They organize scientific conferences ryzyko samobójstwa. Kolejną ważną trudnością analizowaną przez naukowców z Wielkiej Brytanii jest doświadczanie przez studentów poczucia porażki, stresu czy specyficznych problemów w nauce (problemy z zapamiętywaniem i rozumieniem, zbyt duża ilość materiału do przetworzenia). Analizowanymi kwestiami są ponadto niepełnosprawność, problemy medyczne, psychiczne i rodzinne osób podejmujących naukę. Niektóre czynniki, takie jak trudności w dostępie do wsparcia, wiążą się z realiami życia uniwersyteckiego [National Confidential Inquiry into Suicide and Homicide by People with Mental Illness (NCISH), 2017].

Mimo zachodzących zmian można zaobserwować wiele trudności związanych $\mathrm{z}$ adaptacją $\mathrm{w}$ nowym środowisku, także w grupie studentów (Zimbardo i Weber, 1997). Studiowanie często wiąże się z radykalną przemianą stylu życia, ponieważ młodzi ludzie przeprowadzają się do innego miasta, zmieniają warunki zamieszkania i muszą na co dzień współdziałać $\mathrm{z}$ innymi, nowo poznanymi osobami. Jedna $z$ badanych (19 lat) podzieliła się następującą historią: „Nagle musiałam zamieszkać w akademiku. Bez wygód, które miałam w domu u rodziców. Współlokatorka się mną nie interesowała. Miałam za dużo swobody, mogłam wracać do domu, o której chciałam, pić, ile chciałam, i robić, co chcę. Później się zagubiłam. Spróbowałam używek. Prawie wyleciałam z wymarzonego kierunku. To mnie załamało i postanowiłam się zabić”. W literaturze przedmiotu można znaleźć informacje o ważnej korelacji między samooceną a zachowaniami autodestrukcyjnymi (Hoff, 1991).

Korzystny z perspektywy profilaktyki zachowań samobójczych jest fakt, że pracownicy naukowi, doktoranci czy studenci coraz chętniej podejmują działania na rzecz zmniejszenia liczby samobójstw. Organizują konferencje naukowe i wystawy prezentujące określone problemy społeczne, prowadzą badania naukowe, akcje profilaktyczne czy konsultacje psychologiczne i warsztaty specjalistyczne dla osób w sytuacji kryzysowej. Ciekawymi projektami są kampanie społeczne, przykładowo kampania „Życie warte jest rozmowy”, która powstała z inicjatywy Polskiego Towarzystwa Suicydologicznego i Wydziału „Artes Liberales” Uniwersytetu Warszawskiego. Ma ona na celu propagowanie wiedzy o zapobieganiu samobójstwom poprzez plakaty, filmy, konferencje naukowe czy konsultacje psychologiczne.

Na uczelniach działają biura ds. osób niepełnosprawnych, $\mathrm{w}$ których pracują psychologowie i trenerzy. Zgodnie $\mathrm{z}$ analizą badań własnych przeszkodą w zgłaszaniu się osób potrzebujących pomocy do odpowiedniej instytucji uczelnianej jest fakt, że niepełnosprawność nie zawsze kojarzy się z trudnościami natury psychicznej. Z przeprowadzonych badań wynika, iż wielu studentów nie dysponuje informacjami na temat działalności biura - o jego istnieniu dowiadują się zazwyczaj przez przypadek. Być może funkcjonowanie ochrony zdrowia na uniwersytetach można by poprawić przez dokładniejsze oznaczenie treści związanych z pomocą na stronach internetowych. Przykładowo na stronie WWW Centrum Pomocy Psychologicznej Uniwersytetu Warszawskiego, działającego od marca 2018 roku, podano dane umożliwiające 
and exhibitions presenting specific social problems; they conduct scientific research, preventive actions or psychological consultations and specialist workshops for people in a crisis. Interesting projects are social campaigns, for example the campaign "Life is worth a conversation," which was founded on the initiative of the Polish Suicidological Association and the "Artes Liberales" Faculty of the University of Warsaw. It aims to promote knowledge about suicide prevention through posters, films, scientific conferences and psychological consultations.

There are offices for the disabled at universities, where psychologists and trainers work. According to the analysis of the author's own research, the obstacle in reporting people who need help to the appropriate university institution is the fact that disability is not always associated with mental difficulties. The research shows that many students do not have information about the office's activities - they usually learn about its existence by accident. Perhaps the functioning of healthcare at universities could be improved by more accurately identifying the content of help on websites. For example, on the website of the Centre for Psychological Assistance of the University of Warsaw, which operates since March 2018, specific data is provided to use selected services (Uniwersytet Warszawski: Centrum Pomocy Psychologicznej UW).

As part of Marie Curie-Skłodowska University, there is the Support Team for People with Disabilities, which is to support the development of students with difficulties or at risk of social exclusion (Uniwersytet Marii Curie-Skłodowskiej w Lublinie: Zespół ds. Obsługi Osób Niepełnosprawnych). The university also has an Academic Support Centre, which brings together students of the last years of psychology. Members of the organisation are on psychological duties, organise specialised workshops and conferences to promote the idea of mental hygiene.

Another university that provides broadly understood support is the Jagiellonian University in Krakow. On the website of the Department for People with Disabilities, one can find a lot of information about multifaceted help, also the one connected with mental disorders. Once the student submits the appropriate medical documentation, employees can help in obtaining psychological or psychiatric help, or a dean's leave. There is information on the website: "Support is directed to students who make the effort to change. Students are required to submit up-to-date medical documentation confirming they remain in treatment" (Uniwersytet Jagielloński w Krakowie: Kto może skorzystać ze wsparcia).

There is also an Office for the People with Disabilities at the University of Opole. The Office helps students who ask for support and document their health situation. Employees interview the person reporting to the office to learn about their health and academic situation (Biuro Osób Niepełnosprawnych Uniwersytetu Opolskiego: O Biurze).

Iwona Koszewska, psychiatrist, chairwoman of the Working Group for the Prevention of Suicide and Depression, which operates under the National Health Program at the Ministry skorzystanie z wybranych usług (Uniwersytet Warszawski: Centrum Pomocy Psychologicznej UW).

W ramach UMCS funkcjonuje Zespół ds. Obsługi Osób Niepełnosprawnych, który ma sprzyjać rozwojowi studentów z trudnościami lub zagrożonych wykluczeniem społecznym (Uniwersytet Marii Curie-Skłodowskiej w Lublinie: Zespół ds. Obsługi Osób Niepełnosprawnych). Na uniwersytecie działa także Akademickie Centrum Wsparcia, zrzeszające studentów ostatnich lat psychologii. Członkowie organizacji odbywają dyżury psychologiczne, organizują warsztaty specjalistyczne i konferencje, które mają popularyzować ideę higieny psychicznej.

Kolejnym uniwersytetem, który udziela szeroko rozumianego wsparcia, jest Uniwersytet Jagielloński w Krakowie. Na stronie Działu ds. Osób Niepełnosprawnych można uzyskać wiele informacji na temat wielopłaszczyznowej pomocy, związanej również z zaburzeniami natury psychicznej. Po złożeniu przez studenta odpowiedniej dokumentacji medycznej pracownicy mogą pomóc w uzyskaniu konsultacji psychologicznej, psychiatrycznej czy urlopu dziekańskiego. Na stronie WWW znajduje się informacja: „Wsparcie skierowane jest do studentów, którzy podejmują wysiłek zmiany. Studenci zobowiązani są do złożenia aktualnej dokumentacji medycznej potwierdzającej pozostawanie w leczeniu" (Uniwersytet Jagielloński w Krakowie: Kto może skorzystać ze wsparcia).

Również na Uniwersytecie Opolskim działa Biuro Osób Niepełnosprawnych, udzielające pomocy studentom, którzy poproszą o wsparcie i udokumentują swoją sytuację zdrowotną. Pracownicy przeprowadzają rozmowę z każdą osobą zgłaszającą się do biura, aby poznać jej sytuację zdrowotną i akademicką (Biuro Osób Niepełnosprawnych Uniwersytetu Opolskiego: O Biurze).

Iwona Koszewska, psychiatra, przewodnicząca Zespołu Roboczego ds. Zapobiegania Samobójstwom i Depresji, który działa w ramach Narodowego Programu Zdrowia przy Ministerstwie Zdrowia, pisze: „Zapobieganie samobójstwom jest problemem nas wszystkich, nie tylko specjalistów. To problem dla rodziny, nauczycieli, pedagogów, duchownych, przełożonych. Jest to też wyzwanie dla mediów. Potrzeba edukacji całego społeczeństwa w zakresie reagowania na zagrożenie samobójstwem osób z naszego otoczenia. Powszechnie znany jest efekt Wertera (bohater powieści Goethego), czyli niekorzystnego wpływu informacji o samobójstwie (powtórzenie przez innych tej samej metody, zwiększenie liczby usiłowań/ prób). Zespół Roboczy ds. Zapobiegania Samobójstwom i Depresji został utworzony w sierpniu 2016. Staramy się przeciwdziałać w rażących sytuacjach związanych z efektem Wertera, zazwyczaj z powodzeniem, gdyż często niewłaściwe informowanie o samobójstwach wynika $\mathrm{z}$ braku wiedzy" (Aby halny nikogo nie zabrał, 2017). Bardzo pomocne w kontekście zapobiegania samobójstwom jest zjednoczenie różnych środowisk naukowych, społecznych i zawodowych. Tylko ujednolicone działania mogą przynieść realne efekty i umożliwić prewencję samobójstw.

Poza granicami Polski prowadzone są akcje informacyjne i profilaktyczne skierowane do studentów mające na celu 
of us, and not just specialists. This is a problem for the family, teachers, educators, clergy and superiors. It is also a challenge for the media. It is necessary to educate the entire society in how to respond to the threat of suicide. The Werther effect (the hero of Goethe's novel), i.e. an unfavourable effect of information about suicide (repetition of the same method by others, increasing the number of suicide attempts), is commonly known. The Working Group for the Prevention of Suicide and Depression was created in August 2016. We are trying to counteract, usually successfully, in glaring situations related to the Werther effect, because often incorrect way of informing about suicide is due to lack of knowledge" (Aby halny nikogo nie zabrał, 2017). Uniting different scientific, social and professional environments is very helpful in the context of suicide prevention. Only unified actions can bring real effects and prevent suicide.

Outside Poland, information and preventive campaigns directed at students are carried out, which aim at counteracting life-threatening situations. For example, universities in the United Kingdom and PAPYRUS (a British charity that deals with preventing suicides of young people) have published guidelines to help universities prevent student suicide. The guidelines cover the following areas: actions to prevent suicide of young people, ways of intervention, ability to react to suicides, analysis of case studies to overcome problems in the future, creating checklists to ensure the safety of societies (Universities UK: Suicide in student population). Similar guidelines were developed by the World Health Organization (2018). In the document National suicide prevention strategies: progress, examples and indicators, it was stated that a good national policy is necessary to raise the level of suicide prevention. The document aims to inspire governments and decision-makers to establish their own national suicide prevention strategy. Examples of the World Health Organization from each region show the diversity of approaches and present selected indicators. Elements to develop, implement and evaluate a national strategy to prevent suicide were described, as well as activities to overcome barriers that differ depending on the cultural and social specificity of a given country (World Health Organization, 2018).

\section{CONCLUSIONS}

The following conclusions relate to research carried out so far at Marie Curie-Skłodowska University. Some of the issues raised here have not been described in the research part, but are the conclusions drawn from all the performed analyses.

1. According to the respondents, adaptation in the new environment is a significant problem. Students enumerated longing for home, friends or previous habits (e.g. helping their relatives in everyday activities).

2. Above all, difficulties in relationships, especially those related to communication, were listed by the respondents.

3. The most common causes of self-destructive behaviours may be mental difficulties (mental illnesses and disorders, or a nervous breakdown). przeciwdziałanie sytuacjom zagrażającym życiu. Przykładowo uniwersytety w Wielkiej Brytanii i PAPYRUS (brytyjska organizacja charytatywna zajmująca się zapobieganiem samobójstwom młodych osób) opublikowały wskazówki, które mają pomóc uczelniom $\mathrm{w}$ przeciwdziałaniu samobójstwom studentów. Wytyczne obejmują następujące obszary: działania zapobiegające samobójstwom młodych ludzi, sposoby interwencji, umiejętność reagowania na samobójstwa, analiza studiów przypadków w celu zniwelowania problemów w przyszłości, tworzenie list kontrolnych w kontekście zapewnienia bezpieczeństwa społeczeństwom (Universities UK: Suicide in student population).

Podobne wytyczne opracowała Światowa Organizacja Zdrowia (2018). W dokumencie Krajowe strategie zapobiegania samobójstwom: postęp, przykłady i wskaźniki stwierdzono, że do podniesienia poziomu prewencji samobójstw niezbędna jest dobra polityka krajowa. Dokument ma inspirować rządy i decydentów do ustanowienia własnej, krajowej strategii zapobiegania samobójstwom. Przykłady Światowej Organizacji Zdrowia z każdego regionu pokazują różnorodność podejść i prezentują wybrane wskaźniki. Opisano elementy służące opracowaniu, wdrożeniu i ocenie krajowej strategii zapobiegania samobójstwom, jak również przedstawiono działania mające na celu pokonanie barier, które różnią się w zależności od specyfiki kulturowo-społecznej danego kraju (World Health Organization, 2018).

\section{WNIOSKI}

Poniższe wnioski dotyczą badań przeprowadzonych dotąd na UMCS. Niektóre poruszone tu zagadnienia nie zostały opisane w części badawczej, lecz są wnioskami płynącymi z całości dokonanych analiz.

1. Według respondentów poważny problem stanowi trudność $\mathrm{z}$ adaptacją $\mathrm{w}$ nowym środowisku. Studenci wymieniali tęsknotę za domem, znajomymi czy wcześniejszymi przyzwyczajeniami (np. pomocą najbliższych w codziennych czynnościach).

2. Do sytuacji problemowych respondenci zaliczają przede wszystkim trudności w relacjach, zwłaszcza te związane z komunikacją.

3. Najczęstszymi powodami zachowań autodestrukcyjnych mogą być trudności natury psychicznej (choroby i zaburzenia psychiczne czy załamanie nerwowe).

4. Ważne jest zapewnienie interdyscyplinarnego podejścia do studentów (organizowanie akcji profilaktycznych, uświadamianie na temat różnych trudności, szczególnie w okresie sesji: jak radzić sobie ze stresem, co robić w obliczu problemów z koncentracją, zapamiętywaniem czy zdawaniem egzaminów).

5. Konieczne są uwrażliwienie społeczności akademickiej, włącznie z wykładowcami, na możliwe trudności studentów w okresie wczesnej i średniej dorosłości oraz przekazanie wiedzy na temat pomocy osobom zagrożonym wykluczeniem społecznym. 
4. It is important to ensure an interdisciplinary approach to students (organising preventive actions, raising awareness about various difficulties, especially during exam sessions how to deal with stress, what to do in the face of problems concentrating, remembering or taking exams).

5. It is necessary to raise awareness of the academic community, including lecturers, to possible difficulties of students in the early and middle adulthood, and to provide knowledge on how to help people at risk of social exclusion.

6. Students should be provided with psychological assistance and measures should be taken to raise awareness about the professionalism of the helping people. Some students do not want to use psychological help because of the social taboos that are still present.

7. According to the respondents (based on their views and experiences), the most common motives of suicide attempts are mental illnesses, lack of financial and psychological support and difficulties in adaptation.

Elements included in the project are listed below. Not all of them are presented in the research part devoted to the analysis of survey results and in-depth interviews.

\section{Description of the selected activities addressed to the students at Marie Curie-Skłodowska University as part of the "Good Life" project}

1. Research in the academic community, diagnosis of the situation of university students in the following areas: experiencing problems and difficulties, ability to cope with crisis, knowledge about the possibilities of getting help (psychological, peer, organisational).

2. Launching an information campaign aimed at providing each first-year student with information on the psychological support available at the Maria Curie-Skłodowska University and the Support Team for the People with Disabilities.

3. Training students in building relationships: shaping a positive relationship with oneself, relationships in a peer group, creating close relationships.

4. Training for students from the Academic Support Centre and scientific circles: communication, psychological help.

5. Art therapy workshops, which aim to provide students with patterns of spending free time as well as developing skills to cope with stress.

6. Designing and implementing the application that will support the project.

7. Creating a group for students who need in-depth therapeutic work.

According to the literature and the analysis of preventive programs, the success of preventive measures is primarily influenced by the multidimensionality of the undertaken activities. The project goes beyond the framework of the questionnaire or in-depth interview methods. The essence of pre-
6. Należy zapewnić studentom pomoc psychologiczną i podejmować działania podnoszące świadomość na temat profesjonalizmu osób pomagających. Część studentów nie chce korzystać z pomocy psychologicznej ze względu na wciąż obecne tabu społeczne.

7. Najczęstszymi motywami prób samobójczych są według ankietowanych (na podstawie ich poglądów i doświadczeń) choroby psychiczne, brak wsparcia finansowego i psychologicznego oraz trudności w adaptacji.

Poniżej wymieniono elementy ujęte w projekcie, $\mathrm{z}$ których nie wszystkie zostały przedstawione w części badawczej, poświęconej analizie wyników ankiety oraz wywiadów pogłębionych.

\section{Opis wybranych działań skierowanych do studentów UMCS w ramach projektu „Dobre życie”}

1. Badania w społeczności akademickiej, diagnoza sytuacji studentów uniwersytetu w następujących obszarach: doświadczanie problemów i trudności, umiejętność radzenia sobie w kryzysie, wiedza na temat możliwości uzyskania pomocy (psychologicznej, koleżeńskiej, organizacyjnej).

2. Podjęcie akcji informacyjnej, której celem będzie dostarczenie każdemu studentowi pierwszego roku informacji na temat dostępnego na UMCS wsparcia psychologicznego, a także Zespołu ds. Obsługi Osób Niepełnosprawnych.

3. Szkolenia z zakresu budowania relacji: kształtowanie pozytywnej relacji z samym sobą, relacje w grupie rówieśniczej, tworzenie bliskich relacji.

4. Szkolenia dla studentów z Akademickiego Centrum Wsparcia i kół naukowych: komunikacja, pomoc psychologiczna.

5. Warsztaty arteterapeutyczne, których celem jest dostarczenie studentom wzorców spędzania czasu wolnego, a także rozwijanie umiejętności radzenia sobie ze stresem.

6. Zaprojektowanie i wdrożenie aplikacji, która będzie wspomagała działania projektu.

7. Stworzenie grupy dla studentów potrzebujących pogłębionej pracy terapeutycznej.

Zgodnie z literaturą przedmiotu i analizą programów profilaktycznych na sukces działań o charakterze prewencyjnym wpływa przede wszystkim wielowymiarowość podejmowanych aktywności. Projekt wychodzi poza ramy badania metodami kwestionariuszowymi czy za pośrednictwem wywiadu pogłębionego. Istotą działań profilaktycznych mogą się stać warsztaty i szkolenia specjalistyczne dla jak największej liczby osób, które w przyszłości będą w stanie rozpoznawać czynniki ryzyka. Ważną umiejętnością staje się odpowiednia komunikacja w sytuacji zagrożenia. Dzięki wiedzy i umiejętnościom praktycznym ludzie z najbliższego otoczenia osób z tendencjami samobójczymi będą mogli rozpoznać syndrom presuicydalny - a natychmiastowa reakcja może się przyczynić do znaczącego spadku liczby samobójstw. 
for as many people as possible who will be able to recognise risk factors in the future. Appropriate communication in an emergency situation becomes an important skill. Thanks to knowledge and practical skills, people from the immediate environment of people with suicidal tendencies will be able to recognize presuicidal syndrome - and an immediate response can contribute to a significant decrease in the number of suicides.

\section{Conflict of interest}

The author does not report any financial or personal connections with other persons or organisations that could adversely affect the content of the publication and claim the right to publish it.

\section{References / Piśmiennictwo}

Aby halny nikogo nie zabrał. Z dr Iwoną Koszewską, przewodniczącą Zespołu Roboczego ds. Zapobiegania Samobójstwom i Depresji, rozmawia Magdalena Bajer. Forum Akademickie 2017; 7-8. Available from: https://prenumeruj.forumakademickie.pl/ fa/2017/07-08/aby-halny-nikogo-nie-zabral/ [cited: 11 July 2019].

Barber ME, Marzuk PM, Leon AC et al.: Aborted suicide attempts: a new classification of suicidal behavior. Am J Psychiatry 1998; 155: 385-389.

Biuro Osób Niepełnosprawnych Uniwersytetu Opolskiego: O Biurze. Available from: http://bon.uni.opole.pl/o-biurze/ [cited: 10 July 2019].

Brodniak WA: Ramowy program zapobiegania samobójstwom w Polsce na lata 2012-2015. Instytut Psychiatrii i Neurologii, Warszawa 2012.

Durkheim E: Le suicide. Étude de sociologie. Paryż 1976.

Fundacja Zobacz... JESTEM: Samobójstwa u młodzieży w liczbach. Available from: http://zobaczjestem.pl/samobojstwa-u-mlodziezy-liczbach/ [cited: 10 July 2019].

Gask L, Coupe N, McElvenny D et al.: Pilot study evaluation of suicide prevention gatekeeper training utilising STORM in a British university setting. Br J Guid Counc 2017; 45: 593-605.

Główny Urząd Statystyczny: Zamachy samobójcze w 2016 r. Available from: https://stat.gov.pl/files/gfx/portalinformacyjny/pl/defaultaktualnosci/5746/5/1/1/zamachy_samobojcze__w_2016_r..pdf [cited: 10 July 2019].

Gmitrowicz A, Makara-Studzińska M, Młodożeniec A: Ryzyko samobójstwa u młodzieży. Diagnoza, terapia, profilaktyka. Wydawnictwo Lekarskie PZWL, Warszawa 2015.

Godoy Garraza L, Peart Boyce S, Walrath C et al.: An economic evaluation of the Garrett Lee Smith Memorial Suicide Prevention Program. Suicide Life Threat Behav 2018; 48: 3-11.

GOV.UK: Suicide prevention: resources and guidance. Available from: https://www.gov.uk/government/collections/suicide-preventionresources-and-guidance [cited: 10 July 2019].

Harrod CS, Goss CW, Stallones L et al.: Interventions for primary prevention of suicide in university and other post-secondary educational settings. Cochrane Database Syst Rev 2014; (10): CD009439.

Hoff AL: Crisis intervention in schools. In: Leenaars AA, Wenckstern S (eds.): Suicide Prevention in Schools. Hemisphere Publishing Corporation, New York, Washington, Philadelphia, London 1991: 133

Hołyst B: Suicydologia. LexisNexis, Warszawa 2002.

Hołyst B, Staniaszek M, Binczycka-Anholcer M (eds.): Samobójstwo. Polskie Towarzystwo Higieny Psychicznej, Warszawa 2002.

Klamut R: Źródło motywacji podmiotowej - potrzeba sensu życia. Zeszyty Naukowe Politechniki Rzeszowskiej. Ekonomia i Nauki Humanistyczne 2004; 14: 49-60.

\section{Konflikt interesów}

Autorka nie zglasza żadnych finansowych ani osobistych powiazań z innymi osobami lub organizacjami, które moglyby negatywnie wplynąć na treść publikacji oraz rościć sobie prawo do tej publikacji.

Mishara BL, Kerkhof AJFM (eds.): Suicide Prevention and New Technologies. Evidence Based Practice. Palgrave Macmillan, London 2013.

Napieralska E, Kułaga Z, Gurzkowska B et al.: Epidemiologia zgonów dzieci i młodzieży z powodu samobójstw w Polsce w latach 1999-2006. Probl Hig Epidemiol 2010; 91: 92-98.

National Confidential Inquiry into Suicide and Homicide by People with Mental Illness (NCISH): Suicide by children and young people. University of Manchester, Manchester 2017.

O’Connor R, Sheehy N: Zrozumieć samobójcę. Gdańskie Wydawnictwo Psychologiczne, Gdańsk 2002.

Płużek Z: Samobójstwo jako wyraz autodestrukcji. In: Oleś P (ed.): Wybrane zagadnienia $\mathrm{z}$ psychologii osobowości. Towarzystwo Naukowe Katolickiego Uniwersytetu Lubelskiego, Lublin 1997: 11-39.

Policja online: Wybrane statystyki: zamachy samobójcze. Available from: http://statystyka.policja.pl/st/wybrane-statystyki/zamachy-samobojcze [cited: 10 July 2019].

Polskie Towarzystwo Suicydologiczne: Statut Polskiego Towarzystwa Suicydologicznego. Available from: http://suicydologia.org/statut/ [cited: 10 July 2019].

Shreve BW, Kunkel MA: Self-psychology, shame, and adolescent suicide: theoretical and practical considerations. J Couns Dev 1991; 69: 305-311.

Stein D, Apter A, Ratzoni G et al.: Association between multiple suicide attempts and negative affects in adolescents. J Am Acad Child Adolesc Psychiary 1998; 37: 488-494.

Światowa Organizacja Zdrowia, Polskie Towarzystwo Suicydologiczne: Zapobieganie samobójstwom. Poradnik dla pracowników mediów. Polskie Towarzystwo Suicydologiczne, Genewa, Warszawa 2003. Available from: http://www.who.int/mental_health/prevention/ suicide/en/suicideprev_media_polish.pdf [cited: 10 July 2019].

Universities UK: Suicide in student population. Available from: https://www.universitiesuk.ac.uk/policy-and-analysis/Pages/student-suicide.aspx [cited: 10 July 2019].

University of Bristol: Bristol Student Mental Health and Wellbeing Survey 2018: Preliminary Analysis. Bristol 2018, unpublished.

Uniwersytet Jagielloński w Krakowie: Kto może skorzystać ze wsparcia. Available from: https://don.uj.edu.pl/dla-studentow/rodzaj-trudnosci/zaburzenia-psychiczne/dla-kogo [cited: 10 July 2019].

Uniwersytet Marii Curie-Skłodowskiej w Lublinie: Zespół ds. Obsługi Osób Niepełnosprawnych. Available from: https://www.umcs. $\mathrm{pl} / \mathrm{pl} /$ zespol-ds-obslugi-osob-niepelnosprawnych,3222.htm [cited: 10 July 2019].

Uniwersytet Warszawski: Centrum Pomocy Psychologicznej UW. Available from: https://bon.uw.edu.pl/uslugi/dyzur-psychologa/ [cited: 10 July 2019].

World Health Organization: National suicide prevention strategies: progress, examples and indicators. 2018. Available from: https:// www.who.int/mental_health/suicide-prevention/national_strategies_2019/en/ [cited: 10 July 2019].

Woźniak RB: U podstaw socjoglobalistyki. Koncepcje i zagrożenia. Drukarnia Kadruk, Szczecin 2009: 161-167.

Yalom ID: Psychoterapia egzystencjalna. Instytut Psychologii Zdrowia, Warszawa 2008.

Zamachy samobójcze od 2017 roku. Available from: http://www.statystyka.policja.pl/st/wybrane-statystyki/zamachy-samobojcze/63803,Zamachy-samobojcze-od-2017-roku.html [cited: 10 July 2019].

Zimbardo PG, Weber AL: Psychology. Longman, New York 1997. 